\title{
The Thomistic Dissolution of the Logical Problem of Evil
}

\author{
Edward Feser
}

check for updates

Citation: Feser, Edward. 2021. The Thomistic Dissolution of the Logical Problem of Evil. Religions 12: 268. https://doi.org/10.3390/rel12040268

Academic Editor: James Sterba

Received: 20 February 2021

Accepted: 9 April 2021

Published: 13 April 2021

Publisher's Note: MDPI stays neutral with regard to jurisdictional claims in published maps and institutional affiliations.

Copyright: (C) 2021 by the author. Licensee MDPI, Basel, Switzerland. This article is an open access article distributed under the terms and conditions of the Creative Commons Attribution (CC BY) license (https:// creativecommons.org/licenses/by/ $4.0 /)$.
Department of Social Sciences, Pasadena City College, Pasadena, CA 91106, USA; ecfeser@pasadena.edu

\begin{abstract}
In his book 'Is a Good God Logically Possible?', James Sterba argues that the existence of much of the evil to be found in the world is logically incompatible with the existence of God. I defend the Thomistic view that when one properly understands the nature of God and of his relationship to the world, this so-called logical problem of evil does not arise. While Sterba has responded to the version of the Thomistic position presented by Brian Davies, I argue that his response fails.
\end{abstract}

Keywords: problem of evil; theodicy; Thomas Aquinas; James P. Sterba; Brian Davies

Is the existence of God logically compatible with the existence of evil? Or is there a strict contradiction between the two? The "logical problem of evil" is the problem facing the theist of showing that the appearance of contradiction is illusory. J. L. Mackie famously argued that the contradiction is real, so the problem cannot be solved and theism is refuted. ${ }^{1}$ Alvin Plantinga is widely thought to have shown that Mackie was wrong, so the most that the atheist can aim for is an "evidential argument from evil" according to which the reality of evil makes God's existence improbable but not impossible. ${ }^{2}$ James Sterba has recently argued that Mackie was right after all, or at any rate that Plantinga and others have failed to show otherwise. ${ }^{3}$ Central to his argument is the assumption that God is obligated to obey moral imperatives such as the "Pauline Principle" that we may never do evil that good may come of it. If God existed, Sterba claims, he would be violating this principle by either willing or permitting evil for the sake of a greater good, and therefore be less than perfectly good himself. Indeed, in light of the evil that actually exists in our world, he would be "more immoral than all of our historical villains taken together." 4

In this paper, I will explain why, from a Thomistic point of view, the so-called logical problem of evil (and, for that matter, the evidential problem of evil) cannot arise. ${ }^{5}$ For the Thomist, when one properly understands what God is and what morality and moral agents are, it simply makes no sense to think of God as less than perfectly good or as morally obligated to prevent the evil that exists. The "problem" rests on a category mistake. The reasons have nothing essentially to do with the arguments of Plantinga and company, which I will not be defending. They do have to do with considerations raised by the Thomist philosopher Brian Davies, to whom Sterba has responded. ${ }^{6}$ But while I agree with the substance of Davies' views and will be defending him against Sterba, I will largely be focusing on Thomistic considerations other than the ones that Sterba addresses when replying to Davies.

Aquinas and the Thomistic tradition to which his thought gave rise have, of course, been extremely influential in the history of theology and philosophy of religion, and that alone makes it worthwhile to consider how the problem of evil looks from the Thomist's point of view. But I hasten to emphasize that the main ideas I will be expounding by no means reflect merely that particular point of view. On the contrary, though some of my

\footnotetext{
(Mackie 1955).

Cf. (Plantinga 1977). The "evidential" version of the problem of evil is famously presented by (Rowe 1979).

(Sterba 2019).

Ibid., p. 192.

For a survey of Thomistic writing on the problem of evil, see chapter 5 of (Shanley 2002).

Cf. (Davies 2006). Sterba responds to Davies in chapter 6 of (Sterba 2019).
} 
formulations will be distinctively Thomistic, the overall picture reflects the broad tradition of classical theism, which has ancient roots in Aristotelianism and Neo-Platonism; was developed in medieval times by Anselm, Aquinas, and other Scholastics in the Christian context, Maimonides and others in the Jewish context, and Avicenna and others in the Islamic context; and deeply informs the teaching of the Roman Catholic Church, Eastern Orthodoxy, and the earliest Protestant Reformers alike. In other words, the conception of God and his relationship to the moral order that I will be presenting is, historically speaking, the mainstream position.

As Davies has in several places lamented, much contemporary philosophy of religion, whether atheist or theist, presupposes a very different and excessively anthropomorphic conception of God that he has labeled "theistic personalism." ${ }^{7}$ That is certainly true of recent discussion of the problem of evil, and of Sterba and Plantinga alike. For it is only when we attribute to God features that can intelligibly be said to belong only to finite agents that it can seem appropriate either to attack or defend his moral virtue. That is not because God is less than a morally good person, but precisely because he is infinitely more than that.

\section{The Natural Order}

Here is the executive summary: For Thomists and other classical theists, God is utterly distinct from the natural order of things, creating and sustaining it in being ex nihilo while being in no way affected by it in turn. But the "logical problem of evil" implicitly presupposes that God is himself part of the natural order, or at least causally related to it in something like the way that entities within that order are related to one another. Hence, the "problem" rests on a category mistake, so to expose the mistake is to dissolve the problem.

Naturally, this needs spelling out. Let us begin with the Thomistic account of the natural order. ${ }^{8}$ The first thing to say is that this order comprises a collection of interrelated substances, each with its own distinctive essence or nature, and manifesting properties and causal powers grounded in those essences or natures. For example, sulfur is a substance, which, by virtue of its essence, is yellow in color and has a power to generate flame, which is triggered when the sulfur is heated. A tree is a substance which, by virtue of its essence, sinks roots into the earth so as to stabilize it and take in water, grows leaves and bark, and carries out photosynthesis. A beaver is a substance which, by virtue of its essence, has iron-rich teeth, uses them to gnaw at and fell trees, and then uses the wood from the trees to build damns and shelters.

These are examples of physical substances, which in Thomistic metaphysics are taken to be composites of form and matter. ${ }^{9}$ Matter is what individuates physical substances, tying down the essence definitive of a natural kind to a particular individual, time, and place. Form is what organizes the matter so that the resulting substance operates in the way characteristic of things of that kind. For example, there is treeness considered as an abstract universal, and there is the concrete particular tree standing at the rear left of my backyard, the concrete particular tree standing in my neighbor's front yard, and so on. Though having treeness in common, these concrete particulars are distinct individuals because they are associated with different bits of matter. That the matter constitutes a tree in each case rather than some other kind of thing is due to its having taken on the form or organizational structure characteristic of trees.

Form, matter, and causal powers are in turn analyzed by the Thomist in terms of the notions of actuality and potentiality. Matter considered in abstraction from form is

7 For example, in (Davies 2021), chapter 1. Though Davies does not use the label in (Davies 2006), theistic personalism is the view he has in mind when criticizing the ideas of philosophers like Richard Swinburne at pp. 52-54, 59-62, and 93-95 of that book.

8 For a detailed exposition and defense of the metaphysical ideas discussed in this section, see chapter 2 of (Feser 2009), and for an even more detailed exposition and defense, see (Feser 2014b).

9 Thomists also hold that the larger created order includes incorporeal substances-namely angels, conceived of as creatures of pure intellect. But since the points I want to make do not strictly require a discussion of angels, and since this paper is long enough as it is, I will put the topic to one side. 
merely potentially a tree, or a beaver, or sulfur. The form it takes on actualizes one of these potentials, resulting in a physical substance of a specific kind. The powers characteristic of that substance are, in turn, themselves potentialities, and they can be of either an active or passive sort. An active potentiality is a capacity to affect other things, such as sulfur's capacity to burn other things when ignited, or a beaver's capacity to damage or fell a tree. A passive potentiality is a liability to be affected by other things, such as a tree's liability to be felled or a beaver's liability to be killed by a predator.

Potentialities of either kind always involve a teleology or directedness of at least a rudimentary sort, where this directedness is toward ends or outcomes that reflect the distinctive essence of the thing which has the potentiality. Sulfur is by virtue of its nature directed or aimed toward generating flame when the right triggering conditions are present. A tree is by virtue of its nature directed or aimed toward sinking roots into the ground and growing leaves and bark. A beaver is by virtue of its nature directed or aimed toward gnawing at trees, felling them, and then using them to construct dams and shelters. The matter of which any physical substance is composed is directed or aimed toward taking on the form of a different kind of substance when the conditions are right. For example, the matter that makes up a tree is directed or aimed toward becoming ash when flame is applied to it long enough, toward becoming dry and dead wood when the tree is felled, toward becoming nutritive material when an organism like a termite ingests it, and so on.

A law of nature, in Thomist metaphysics, is essentially a description of the way a physical substance will tend to operate given its nature or essence. For example, to say that it is a law of chemistry that sulfur generates flame when heated is a roundabout way of saying that given the nature or essence of sulfur, it has a power of generating flame which will be triggered when it is heated. To say that it is a law of physics that an object at rest will stay at rest and an object in motion will remain in motion unless acted on by an outside force (Newton's law of inertia) is a roundabout way of describing how a physical object will tend to move or not move given its nature or essence. And so on. Other laws describe how systems of physical substances behave. For example, Kepler's laws of planetary motion describe how, by virtue of their natures, physical substances of a certain mass will behave relative to one another when they are in proximity to each other. Thus, the natures or essences of things, which underlay their properties and powers and thus determine the ways they tend to behave when those powers are manifested, are metaphysically more fundamental than laws.

Goodness or badness as general features of the world are, on this account, to be analyzed in terms of how fully a substance actualizes the potentials which, given its nature, it needs to actualize in order to be a flourishing instance of its kind. For example, a tree's nature aims or directs it toward sinking roots into the ground, growing bark and leaves, carrying out photosynthesis, and so on. To the extent that a tree realizes these ends, it is a good tree in the sense of a good specimen of the tree kind. To the extent that it fails to realize them (due, say, to termite damage, or disease), it is a bad tree in the sense of a defective specimen.

Sometimes what is good for one kind of physical substance, given its nature, will be bad for another kind, given its different nature. For example, it is good for beavers to gnaw at and fell trees. They cannot flourish as the kinds of things they are without doing so. But obviously, their doing so is not good for trees. Now, a natural order with both beavers and trees in it has more kinds of goodness in it than a natural order without both. Hence, an increase in the amount of goodness in the world can in some cases entail also an increase in certain kinds of badness as a necessary concomitant. 


\section{The Moral Order}

Obviously, so far, none of this has to do with goodness or badness in the moral sense. Rather, I am describing more general kinds of goodness or badness of which, for the Thomist, distinctively moral goodness and badness are species. ${ }^{10}$

This brings us to human beings, whose nature or essence, according to Thomism, is to be rational social animals. We are a kind of animal because among our powers are those characteristic of animals-taking in nutrients, going through a growth cycle, reproducing ourselves, taking in information about the world via sensory experience, being prompted to action by appetites, and having the capacity for locomotion or self-movement. We are rational animals insofar as, unlike other animals, we can form abstract concepts, put these concepts together into propositions, and reason logically from one proposition to another. A byproduct of these rational powers is will or rational appetite, which is the capacity to be moved to action by what reason apprehends to be good (as opposed to by mere sensory input or by pleasure or the avoidance of pain). If a thirsty dog sees water, its thirst will prompt it to drink unless there is some countervailing impulse, such as a feeling of fear generated by the sight of an approaching predator. As animals, human beings will also be influenced by such appetites-but, on top of that, will be able rationally to assess the situation and, if they judge it to be best to do so, to override the stronger appetite that would have determined what a non-rational animal would do. This capacity to be guided by reason rather than sensation and appetite alone is what constitutes the freedom of the will.

Now, as with other physical substances, what is good or bad for us is determined by our nature and the powers that nature gives us, and is to be analyzed in terms of what either facilitates or frustrates the realization of the ends toward which those powers are aimed or directed. For example, as rational creatures our minds are aimed or directed toward knowledge, so it is good for us to acquire knowledge and bad for us to remain ignorant or fall into error. As animals, we need food of a certain kind and amount in order to be healthy, so it is good for us to eat such food and bad for us to have either too little of it or to eat to excess. And so on. These are objective facts rather than matters of personal taste or social convention. That ignorance and gluttony are bad for us is no less objectively true than that having damaged roots or insufficient water is bad for trees.

Morality enters the picture because, unlike trees, we can know what is good or bad for us and choose to act accordingly. A tree that fails to sink sufficiently deep roots into the ground is not a morally bad tree, because it neither knows nor can choose what it does. But a human being can know that it is bad to deceive oneself or to be a glutton, and can choose either to avoid self-deception and gluttony or to engage in them. An action is morally good when it is consistent with the realization of the ends toward which our nature directs us, and morally bad when it frustrates the realization of these ends. A person who habitually performs actions of the former kind has a morally good character, and a person who habitually performs actions of the latter kind a morally bad character.

Virtues and vices concern specific respects in which a person's character might be morally good or bad. For example, a person whose eating habits are conducive to good health and who does not pursue the pleasures of the table in a manner that leads to neglect of more important needs exhibits, at least to that extent, the virtue of temperance. A person who habitually overeats or obsesses over food to the neglect of higher goods exhibits the vice of gluttony.

Now, because we are social animals, what is good or bad for us is also determined in part by our relations to other human beings. For example, like other sexually reproducing animals, we are aimed or directed by nature toward mating with members of the opposite sex, and we thereby produce offspring who are helpless for many years after birth. They need a stable source, not only of material provision, but-since they are immature rational animals —of discipline and instruction in what is useful and good for them. Such biological

10 For detailed exposition and defense of the moral theory discussed in this section, see chapter 5 of (Feser 2009), and (Feser 2014a). 
facts are the foundation of the family as a natural institution, and part of what is good for us by nature is to fulfill our roles within the family. For example, a father is directed or aimed by nature toward providing materially and morally for the family he has played a role in bringing into being. To the extent that he does so, he exhibits a good moral character, and to the extent that he fails to do so he exhibits a bad moral character. Children are directed by nature toward obeying the reasonable instructions of their parents, and exhibit good or bad moral character to the extent they habitually do so or fail to do so. And so on.

There are larger social formations too-local communities, nations, the international order-and what is good or bad for us is also in part a matter of how we relate to members of all of these social orders. Rights and duties of various kinds follow from the different kinds of relations we bear to these other members. For example, since a father is by nature directed toward providing for and instructing his children, they have a right to have their father provide for and instruct them, and the father has a right to the obedience from his children that he needs in order to do those things effectively. And he therefore has a duty to provide these things for them and they have a duty to obey him.

Natural law in the moral sense has to do with the principles for action that follow from these various facts about our nature. For the Thomist, our intellects have as their natural end knowledge of the truth about things, including the truth about what is good for us given our natures. The will, meanwhile, has as its natural end the pursuit of what the intellect takes to be good. Hence, a properly functioning intellect and will-and thus an agent who is thinking and acting rationally-will grasp what is in fact good for us and seek to pursue it. For example, such an agent will see that ignorance and gluttony are bad for us, and thus will choose to avoid these things and to cultivate the virtues that will facilitate doing so. That doing so is morally good for us is a matter of natural law in something like the way that sinking roots into the ground and taking in water through them is good for a tree as a matter of physical law.

In addition to the principles of natural law that reason tells us we ought to pursue, there are human laws - the directives of lawmakers-to which we can be bound. But even these are grounded in the natural law. For example, in order properly to provide for and instruct his children, a father has to be able to issue various directives, some of which go beyond what can be known from natural law. When he tells them that it is bad for them to hit each other and that they ought therefore to refrain from doing so, he is simply calling to their attention something that, had they sufficient use of reason and knowledge, they would see to be true as a matter of natural law. But when he tells them that they have to do their homework before dinner time, he is, as it were, issuing a piece of legislation that goes beyond anything in natural law. That does not, however, make such a directive a mere arbitrary whim. On the contrary, given that it is motivated by facts about the nature of children together with facts about the contingent concrete circumstances in which the family finds itself, it has a perfectly reasonable and objective basis. And that they need, for their flourishing, directives of this kind from their father entails that children ought to obey them no less than they ought to obey those principles more directly grounded in natural law.

It goes without saying that all of this raises many questions and requires elaboration and various qualifications. Working out the details is what moral theory in the Thomistic natural law tradition is about. The point for present purposes is simply to explain in a general way how morality is grounded in the natural order of things. Indeed, the moral order is a part of the larger natural order. Human beings are bound by natural law and human law in the ways that they are because they are physical substances of a certain natural kind, and cannot flourish qua specimens of that kind without obedience to these laws.

\section{Divine Causality}

Now, where does God fit into this picture? The answer is that he does not fit into it at all. He is no more a part of the natural order-and thus no more part of the moral order 
that is a segment of the natural order-than an author is part of a novel or than a painter is part of a painting. Rather, he is the necessary precondition of there being any natural order at all, just as an author is the necessary precondition of there being any novel at all and a painter is a necessary precondition of there being any painting at all. And conceiving of God on the model of a natural substance is like conceiving of an author as an additional character in a novel, or conceiving of a painter as one of the images in a painting.

That there is indeed something standing outside the natural order as its necessary precondition, and that this something has a divine nature, is argued for by the Thomist in various ways. Here I will summarize only the ideas most relevant for present purposes. ${ }^{11}$ In addition to the metaphysical components of physical substances already referred to- form, matter, causal powers, etc.- - the Thomist posits two most fundamental parts: a thing's essence and its existence. Suppose you describe, for someone who has never before heard of any of them, the essence of a lion, the essence of a Tyrannosaurus Rex, and the essence of a unicorn. Suppose you went on to tell him that, of these three creatures, one exists, one used to exist but has gone extinct, and another never existed but is purely legendary. And suppose you asked him to tell you which was which, based on his new knowledge of their essences. Even if your description of the essences of these things was complete and the person you were describing them to had flawless understanding and powers of deduction, he would be unable to tell you. This illustrates the Thomistic thesis that the existence of a natural substance is something distinct from its essence. If it were not, then perfect knowledge of the latter would afford knowledge of the former.

For the Thomist, an essence considered by itself is at most only potentially part of the natural order. That existence is added to an essence is what actualizes this potential. Now, lions are here and now part of the natural order, while Tyrannosauruses used to be part of it but no longer are, and unicorns never were. That entails that existence is being added to the essence of lions, but not to the essences of Tyrannosauruses or unicorns. And whatever is adding it must be doing so here and now and at any moment at which lions exist, and not just at the moment they first came into being. For the essence and existence of a lion remain distinct parts of it now no less than they were before lions were around. Something must, in other words, be conserving or sustaining lions in existence here and now and at every moment at which they exist.

Now, if what is doing this were some cause which itself has an essence distinct from its existence, then it too would need a conserving cause, and we would have an explanatory regress. Such a regress can terminate only in something that can conserve things in existence without itself having to be conserved in existence, something that can actualize the otherwise merely potential existence of other things without itself having to be actualized. The Thomist argues that what can function as an ultimate conserving cause of this sort can only be something in which there is no distinction between its essence and its existence-something whose very essence just is existence, so it need not have existence added to it. It would have to be something devoid of any potentiality for existence standing in need of actualization, but instead be already entirely actual. To use the traditional Aristotelian-Thomistic jargon, it would be actus purus ("pure actuality") and ipsum esse subsistens ("subsistent being itself").

Now, what is true of lions is true of everything else-sulfur, trees, beavers, human beings, and every other substance to be found in the natural order. With each of these things, its essence and existence are distinct, and thus with each of them, it can continue in being as part of the natural order only insofar as existence is continually imparted to it by that which is pure actuality and subsistent being itself. Thomists also argue that, on analysis, there can in principle be only one thing that is pure actuality and subsistent being itself. So, it is the same one conserving cause that is sustaining the entire natural order in being at every moment.

11 For detailed exposition and defense of the theological ideas discussed in this section and the next, see chapter 3 of (Feser 2009), and for an even more detailed exposition and defense, see (Feser 2017). 
Thomists also argue that anything that is pure actuality and subsistent being itself must have a number of further attributes. For example, it must be immutable, given the Aristotelian-Thomistic analysis of change as the actualization of potentiality. For since it is purely actual and without passive potentiality, it cannot be changed. Similarly, it must be immaterial, given the Aristotelian-Thomistic analysis of matter as the potentiality to take on form. It must be eternal in the sense of being altogether outside of time, given its immutability together with the Aristotelian-Thomistic analysis of time as the measure of change. It must be simple or non-composite given its pure actuality together with the fact that anything composed of parts would have potentiality in need of actualization (insofar as it would not exist unless its parts are combined). It must exist of necessity rather than contingently given that it is pure actuality and simple or non-composite, together with the fact that a thing is contingent only if it has potentiality in need of actualization and parts in need of combining.

A further Thomist thesis about the relationship between the natural order and its conserving cause is that the former depends at every moment on the latter for its operation no less than for its existence. Natural substances have their causal power in a secondary or derivative way-like a stick which can move a stone only insofar as it is used by a hand to do so, or an electric motor which can move the wheels of a car only insofar as it draws power from a battery. Hence, without drawing causal power from their conserving cause at every moment at which they operate, natural substances would be as inert as a stick that the hand has dropped to the ground or the motor that has been disconnected from its battery. Since all possible causal power derives in this way from the conserving cause of things, that cause can also be said to be omnipotent.

What I have been summarizing here are the Doctrine of Divine Conservation, according to which the natural order could not continue in being for an instant without God's continually sustaining it; and the Doctrine of Divine Concurrence, according to which natural substances cannot exercise their causal power even for an instant without God's concurring or cooperating with that exercise. It is only in light of these doctrines that we can correctly understand what Thomists, and classical theists in general, mean when they characterize God as First Cause of the natural order. They do not primarily mean "first" in the temporal sense of having gotten the universe going at the Big Bang. To be sure, most classical theists think that God did indeed cause the world to begin at some time in the past, but some think that the world has always been here without beginning. All classical theists agree, however, that whether or not the natural order had a beginning in time, the more important point is that it could not persist in being without divine conservation, and that that is the fundamental way in which God is creator or cause of the world. When speaking of God as First Cause, they also do not mean "first" as opposed to second, third, fourth, etc. The number of members in a causal sequence is not what is at issue. What they mean is that God has causal power in a primary rather than secondary way. That is to say, whereas natural substances have causal power only insofar as they borrow or derive it from something else, God has causal power in a built-in or underived way. For the Thomist, only what is pure actuality with no potentiality requiring actualization can be such a cause in an absolute or unqualified sense.

Because his causal power is of this unqualifiedly primary kind, and because he is immutable, immaterial, eternal, and simple or non-composite, God's causality is radically unlike that of natural substances. When a natural substance brings another into being, it does so by transforming preexisting materials. But that is not how God causes the natural order to exist, because in this case, anything that could serve as preexisting material is itself among the things being caused. When a natural substance brings about an effect, it works through parts (such as the hand you use to move a stick) and itself undergoes change over time as it does so (as when your arm flexes and changes position when moving the stick). Nothing like this happens with divine causality, since God is non-composite, immutable, and eternal. When a natural substance exercises causal power, it does so in accordance with the laws of nature that describe its characteristic mode of behaving. But God is not 
governed by laws of nature, since those laws are themselves precisely among the things he causes in creating the natural order that the laws describe.

For these reasons, the Thomist holds that the language we use when describing God and his causal relationship to the world must be understood in an analogical way, where analogy is a middle ground sort of usage lying between the univocal and equivocal uses of terms. By way of illustration of the idea, consider how we speak of the number 3 as being larger than 2, as standing between 2 and 4, as nearer to 1 than it is to 10, and so on. We are using terms that usually describe spatial relationships, but we are not using them in that sense when describing numbers, which do not exist in space. But we are not using them in an entirely unrelated or equivocal way either. Though 3's standing between 2 and 4 is not exactly the same sort of thing as your house's standing between your neighbor's houses, it is analogous to that. Note that analogical language of the sort in question here is not metaphorical. 3 really is literally between 2 and 4 . It is just that "between" is not used in an identical or univocal sense when we describe numbers and when we describe houses.

"Cause" and related terms are, for the Thomist, to be given an analogical interpretation when applied to God. God's causing the natural order is analogous to a human being's building a house or making a sculpture, but it is very far from being exactly the same sort of thing as that, given divine immateriality, immutability, eternity, simplicity, etc. Indeed, much of what we have to say about the divine nature is along the lines of apophatic or negative theology-saying what God is not, how radically he differs from the natural order he conserves in being.

Now, many theological errors, not only on the part of skeptics but also on the part of naïve religious believers, derive from a failure to keep in mind points like the ones I have been making. For example, skeptics and naïve believers alike often conceive of God and his relation to the natural order on the model of a "god of the gaps." That is to say, they think that the way arguments for God's existence work is by identifying some unusual phenomenon for which we have not yet found a natural explanation, and then appealing to special divine action to fill this explanatory gap. The standard criticism of such arguments is to note that they stand at the mercy of scientific advance, with God having less and less to do the more existing gaps in explanation are filled by further research in physics, chemistry, and so on.

The "god of the gaps" approach is indeed feeble, but it has nothing to do with the arguments of Thomists and other classical theists. They are not trying to fill explanatory gaps within the natural order studied by science, but rather explaining what empirical science itself presupposes but cannot account for-namely, the fact that there is any natural order at all in the first place. The "god of the gaps" approach is like supposing that to say that a painting presupposes a painter amounts to positing an as-yet unseen person lurking somewhere in the image ("Where's Waldo?" style), or that to say that a novel presupposes an author amounts to positing a character in the story who somehow escaped the reader's notice on a first reading. It is a category mistake, resting on a conflation of the primary causality unique to what is pure actuality and subsistent being itself with the secondary causality characteristic of natural substances.

\section{Divine Goodness}

Now, a similar fallacy, I am claiming, underlies the so-called logical problem of evil. To see how, though, a little more stage-setting is required. Let us note first that, despite everything said so far and despite Davies' apt emphasis on distinguishing classical theism from what he calls "theistic personalism," Thomists and other classical theists do not regard God as impersonal. On the contrary, Thomists and most classical theists would attribute intellect and will to God, and these are the properties characteristic of persons. For the Thomist, whatever is in an effect must in some manner preexist in its cause, and since God is the cause of any possible reality other than himself, the essences or natures of all the possible things he might create must in some way exist in him. The traditional way classical theists have understood this is in terms of the thesis-famously associated with 
St. Augustine and adopted by Aquinas-that such essences exist in God in a manner analogous to how ideas or concepts exist in an intellect, and function as the archetypes by reference to which God creates. Given the further Thomistic thesis that will follows upon intellect, if there is something in God analogous to intellect, there must also be in him something analogous to will.

Here as elsewhere, though, it is absolutely crucial to keep in mind the Thomist view that the terms we predicate of God must be understood in an analogical rather than univocal way. God's intellect and will are no more like ours than his causality is like ours. For example, God does not come to know things or engage in any sort of reasoning process, because that would entail change, and he is immutable and eternal. What God knows he knows in a single eternal act; and since he is purely actual and thus without potentiality needing actualization, his knowledge and wisdom are perfect. God's manner of knowing the natural order does not involve any sort of observation of it, because he does not need to be (nor indeed can be, given his immutability) affected by anything distinct from himself in order to know it. Rather, he knows the natural order by knowing himself as the cause of it, just as an author knows the story he has written by virtue of knowing his own mind. Given divine simplicity, we cannot attribute distinct thoughts to God; rather, what he knows he knows in something like a single intellectual act. And so on. God is not impersonal, but neither is he like a human person.

The trouble with what Davies calls theistic personalism is that it models God precisely on human persons, in something like the way that "god of the gaps" theories model God on secondary causes operating within the natural order. It conceives of God as undergoing change and therefore being in time, as causally affected by the natural order, as coming to know that order by observing it, and so on. To be sure, like classical theism, it also thinks of God as immaterial and omnipotent. But given its deviations from classical theism, it nevertheless reduces God's power and independence from matter to something comparable to what we see in the gods of the ancient pantheons. God becomes like Zeus or Odin, or like a character from a modern superhero comic book or movie. (David Bentley Hart aptly characterizes theistic personalism as "monopolytheism" — committed to a view of the divine nature that differs little from that of polytheists except that it reduces the membership of the pantheon down to one. ${ }^{12}$ ) Theistic personalism unwittingly makes of God just another part of the natural order, albeit the most powerful part-not like an author at all, but merely a character in the novel who has superpowers, and not like a painter but merely the most striking image in the painting.

This is the context within which to understand the sense in which God is good, and Davies' objection to characterizing God as a "moral agent."13 The first thing to say is that the Thomist certainly does conceive of God as good, indeed as supremely good. For as I have indicated, goodness, for the Thomist, is to be analyzed in terms of the actualization of the potentials that a thing's nature directs it toward actualizing, and badness in terms of the failure to actualize them. But God is pure actuality, with no unactualized potentiality. Hence, he is perfectly good. To be sure, unlike other things, he is also devoid of potentialities that would have needed actualization in the first place, but that entails more in the way of goodness rather than less. If it is good to actualize a potential for $X$, it is better still never to have been merely potentially $X$, but always to have been actually $X$.

As Barry Miller has suggested, a divine perfection as classical theism understands it is to be understood as a kind of limit case rather than a limit simpliciter. ${ }^{14}$ A limit simpliciter differs only in degree from other instances of that to which it is the limit. For example, the speed of light is the fastest speed at which a physical object can travel, but it differs only in degree from lower speeds. By contrast, a limit case differs absolutely from the instances to which it is a limit, rather than in degree. For example, a speed of $0 \mathrm{~km} / \mathrm{s}$ is not a lowest

\footnotetext{
(Hart 2013, p. 127).

(Davies 2006, p. 92).

(Miller 1996, pp. 7-10).
} 
speed, because it is not a speed at all. Still, the ways that the different degrees of speed are ordered point to this limit case. Divine goodness too can be thought of as a limit case (though, unlike a speed of $0 \mathrm{~km} / \mathrm{s}$, as a maximum rather than a minimum). The degrees of goodness to be found in the natural order point to it, not as a highest degree in the series, but rather as something outside the series on which the series' members converge and can only ever approximate.

Alternatively, divine goodness can be thought of as a kind of paradigm case. A paradigm case is not merely one instance of a kind among others, but rather the standard by reference to which something counts as a member of the kind. For example, the standard meter in Paris was not merely one meter alongside the others, but the standard by reference to which anything else counted as a meter. Or, to take a better example (because it does not involve human convention), Plato's Form of the Good is not merely one instance of goodness alongside the others, but rather the standard by reference to which anything counts as good. For the classical theist, divine goodness is like that. It no more makes sense to think of God as less than perfectly good than it does to think of the Form of the Good as less than perfectly good, or to think of the standard meter as less than a meter long.

Now, this is one obvious respect in which divine goodness is not like the moral goodness exhibited by human beings, which does come in degrees. But there are other respects. For example, human goodness involves possession of moral virtues such as courage, which is the disposition to do the right thing in the face of danger, and temperance, which involves moderation in indulgence of one's appetites. Since God cannot possibly be in danger and has no appetites, he cannot intelligibly be said to possess virtues like courage and temperance. More generally, God is not subject to the natural law, any more than he is subject to physical laws. The natural law is grounded in human nature, just as physical laws are grounded in the natures of physical substances more generally. As the cause of human beings and of physical substances in general, and thus as the cause of the very existence of the natural law as of the existence of physical laws, he can hardly be governed by it.

By no means does this entail, however, that God could by fiat make just anything morally obligatory, such as torturing babies for fun. For, again, what is good or bad for human beings is determined by their essence or nature. Given the essence of human beings, it cannot possibly be good for them to torture babies for fun, so a world in which this is morally obligatory is like a world with round squares-not one that even God could create. (Perhaps God could make creatures of some kind for which torturing babies for fun would be good, but they would not in that case be human, because such a thing could not be good for something with our nature.) So, to suppose that either there exists some moral standard independent of God that he did not create, or he could command just any old thing by fiat - the standard Euthyphro dilemma scenario-is, for the Thomist, a false choice. Nothing at all can exist, including the natural law, unless God creates it. But at the same time, if he creates human beings, and thus the natural law that governs them, then what he commands is constrained by what it is to be a human being.

Since God just is subsistent being itself and the law of non-contradiction is, for the Thomist, simply a reflection of the very nature of being, God's creating things in accordance with this law is ultimately to be analyzed as a matter of his creating in accordance with his own nature. And his doing so entails that there is a sense in which he creates with perfect justice, though there is another sense in which the concept of justice no more applies to God than the notions of courage or temperance do. Traditionally, a distinction is drawn between two main types of justice. Commutative justice has to do with justice in the ways that members of a community deal with one another with regard to respecting property rights, honoring contracts, and the like. Distributive justice has to do with the way that a ruler ensures that those who are under his or her authority receive what is due to them. Now, as Aquinas argues, the notion of commutative justice does not at all apply to God, 
but there is a sense in which the notion of distributive justice does apply to him. ${ }^{15}$ For on the one hand, since God is not a part of the natural order, neither is he a part of the moral order that is a component of the natural order. Hence, he is not subject to natural law and thus not subject to the rules of commutative justice that govern the relationships between rational social animals.

On the other hand, it would be contrary to God's perfect wisdom to create an incoherent world-for example, one in which beavers exist but the trees they need to build their dams and shelters with do not, or in which trees exist but the water they need to draw in through their roots does not. Hence, God creates in such a way that what they require given their nature is provided them-trees for beavers, water for trees, and so on. In that sense he can be said to act in accordance with distributive justice, not because he is indebted to anything he creates, but because the incoherence of creating a world in which things are by nature directed toward ends they cannot even in principle achieve is contrary to God's wisdom.

Of course, while it is true that in general beavers have the trees they need, trees have the water they need, and so on, there are of course many individual cases in which things are not in fact able to realize the ends their natures set for them. There are beavers which cannot find enough trees to fell, trees which die from lack of water or indeed because they are felled by beavers, and so on. But this is because of the aforementioned fact that some natural substances are by nature at cross purposes. Again, for beavers to realize what is good for them requires them to do what is bad for trees. Hence, if you are going to have in the natural order the particular kind of goodness exhibited by beavers, accepting the kind of badness they inflict on trees is "part of the deal." More generally, if you are going to create a natural order with all the specific kinds of goodness that ours exhibits-the goodness of lions, gazelles, birds, worms, bacteria, and so on-then, given their natures, certain sorts of badness (gazelles eaten by lions, worms eaten by birds, diseases caused by bacteria, etc.) are going to be a concomitant. The overall order is good, and the badness that accompanies it is a necessary part of that good, without which that particular kind of good could not exist. You might have a world with things that looked like lions but did not eat gazelles, but they would not be lions. If you want lions, the occasional dead gazelle is part of the package. Indeed, though it is bad for the individual gazelle that it is eaten, it is good for the overall order of the world that it be eaten. For part of the point of their existence is to provide food for lions and thereby contribute to the overall order of things. Hence, while the proximate end of a gazelle (to stay alive) is frustrated, the remote end (serving as lion food) is fulfilled.

In this way, Aquinas argues, the badness in the world is not only not incompatible with divine omnipotence and goodness, but in fact manifests divine omnipotence and goodness insofar as God is able to produce a greater good out of evil. ${ }^{16}$ And this is true for human beings no less than for other creatures. Now, as rational animals, human beings are capable of far greater suffering than non-human animals. But for the same reason we also have, unlike non-human animals, immortal souls-since, the Thomist argues, our rationality entails that our souls are incorporeal and thus do not perish with the death of the body. ${ }^{17}$ Hence the good that God may produce out of the evil we suffer is not primarily to be found in this life but in our unending afterlife. And it includes the offer of the beatific vision, which infinitely outweighs any suffering we could undergo in this life, and which will be refused only to those who refuse the offer. With human beings no less than with the rest of the natural order, then, a greater good will ultimately be drawn out of all the evil that exists. All will in the long run receive no less than what they merit, so perfect justice will be achieved.

15 Summa Theologiae I.21.1.

16 Summa Theologiae I.2.3.

17 For detailed exposition and defense of the immateriality and immortality of the soul, see chapter 4 of (Feser 2009), and my articles (Feser 2013), and (Feser 2018). 


\section{Sterba Contra Davies}

Let us turn, then, to Sterba's response to Davies' presentation of the Thomistic approach to the problem of evil. As I have noted, Davies frames the Thomistic view in terms of the thesis that God is not a "moral agent." ${ }^{18}$ I have also explained why seeing Davies' point does not entail taking God to be impersonal or denying that he is good and just, any more than denying that God is part of the natural causal order governed by physical law entails denying that he is a cause. As when attributing causality to God, so too with attributing goodness to him, we must always keep in mind the ways in which he differs from the natural order no less than the ways he is analogous to it. Davies' point is that atheistic arguments from evil, and too many theistic responses to such arguments, fail to keep this in mind. In particular, they involve fallaciously attributing to God aspects of the goodness of human moral agents that cannot intelligibly be attributed to him, any more than every aspect of natural causes can be attributed to him.

As I have also indicated, a key element in Sterba's formulation of the logical problem of evil is an appeal to the "Pauline Principle" that we may never do evil that good may come of it. ${ }^{19}$ Now, where the evil actions of human beings are concerned, the Thomist position is that God does not cause them but merely permits them. But Sterba points out that at least in some cases, the Pauline Principle would rule out even permitting certain evils, and not merely the doing of evil. For example, a parent who could easily have prevented a child from falling and breaking an arm but refrained from doing so could hardly claim to be blameless on the grounds that he merely permitted the injury in the hope that the child would learn a valuable lesson in safety. To be sure, Sterba also thinks that there are cases where evils permitted, or indeed evils done, are minor enough and the good to be gained great enough that violations of the Pauline Principle could be justified. But he thinks that this is not true of all the evils that exist in the world, so if God existed, then in permitting these evils he would be guilty of an unjustifiable violation of the principle.

But there are two fatal difficulties with this argument. First, the Thomist maintains that the reward of the blessed in the afterlife is of infinite worth, so that, as St. Paul famously writes, "the sufferings of this present time are not worth comparing with the glory that is to be revealed to us" (Romans 8:18, RSV). And God permits the moral evil that exists precisely because he draws this infinite good out of it. Since we are rational animals, we have free will, and thus by nature are directed toward shaping our own destinies. Since we are also social animals, we are also by nature directed toward contributing to shaping the destinies of the larger communities of which we are members, by way of our choices. For God to systematically prevent our choices from having their natural effects (as opposed to the occasional ad hoc miracle) would be to render this natural order pointless, giving us the power to shape our destinies without allowing us actually to do so. That would be as contrary to divine wisdom as making a world with beavers but no trees, or trees but no water. In order to flourish as the kinds of creatures we are, then, we must be permitted to shape our destinies, for good or ill —and, if the latter, then to choose whether or not to face up to the consequences of sin and repent of it. And in doing so we thereby shape our souls and prepare them for the hereafter-where, again, we face the prospect of a reward of infinite magnitude that cannot fail to make the painful process that leads up to it worthwhile. To be sure, Thomists do not think of either the "Free Will Defense" or "Soul-Making Theodicy" as the whole story where evil is concerned, nor do they conceive of them as exonerations of God, because God (not being subject to natural law) does not need exonerating. But free will and soul-making are nevertheless part of the story of why moral evil is permitted to exist.

18 I should note that Davies' fellow Thomist Brian Shanley has objected to this way of putting things, though Davies has defended himself against Shanley. (Cf. Shanley 2002, pp. 110-17; Davies 2006, pp. 98-103). But it seems to me that, at the end of the day, the dispute is largely semantic and that the substance of the Thomistic response to the logical problem of evil does not stand or fall with whether or not one agrees with Davies' way of formulating it.

19 Sterba introduces this theme at pp. 2-4 of (Sterba 2019) and returns to it many times throughout the book, deploying it against Davies in chapter 6. 
Now, Sterba would respond that by interfering with the freedom of evildoers, God would be preserving the freedom of their victims, and Sterba would point out that we take human beings to be morally obligated to prevent horrendous acts of evil even when this would remove some opportunities for soul-making. ${ }^{20}$ So, should not God interfere to prevent such acts? One problem with this response is that it assumes a view about the value of freedom that the Thomist would reject, thus begging the question. Sterba speaks of freedom as if it had to do with there being a finite bundle of opportunities for unconstrained action that stand in need of distribution, where the question is how many of these opportunities should be doled out to evildoers and how many to the innocent. The problem, as he sees it, is that doling out such an opportunity to an evildoer effectively cancels out the opportunity that an innocent person might have (insofar as the latter might be injured, stolen from, etc., and thus to that extent lose out on some opportunity for unconstrained action).

But that is not at all how the Thomist conceptualizes the matter. There is no question of the freedom of evildoers canceling out that of the innocent in the relevant sense. For the freedom of the will of the innocent is in no way affected by the actions of evildoers. If I maim you or steal from you, then I thereby remove from you the opportunity to use a certain body part or piece of property. But I have not thereby taken from you your free will, and thus I have not taken from you your capacity to mold your own moral character. And that is what matters to realizing the possibility of an everlasting reward in the hereafter-one which infinitely outweighs any harm that an evildoer could do with respect to your opportunities for unconstrained action in this life.

Now, Sterba is of course correct that human beings are in general obligated to prevent horrendous acts of evil even though this would remove certain opportunities for soulmaking. But this brings us to the second fatal difficulty with his argument from the Pauline Principle. Human beings are obligated to prevent such horrendous actions-and, more generally, are obligated to obey the Pauline Principle-because they are members of the community of rational social animals governed by natural law, of which the Pauline Principle is a part. Preventing fellow human beings from carrying out such actions is part of the way in which their free choices can positively contribute to shaping the destiny of that community, where making such a contribution is part of the reason they have free will in the first place.

But God is not a part of that community, and thus he is not governed by the natural law, and thus he is not subject to the Pauline Principle. To be sure, that does not entail that God might will or cause moral evil, which for the Thomist he does not. Again, God merely permits such evil. ${ }^{21}$ But even permitting it would violate the Pauline Principle as Sterba understands it, and the point is that God is not bound to refrain from permitting it. To claim that, by permitting horrendous evils, God is violating the Pauline Principle, is like claiming that, by creating the natural order ex nihilo he is violating the law of the conservation of mass, or like claiming that the doctrine of divine concurrence conflicts with the law of inertia. All such claims are category mistakes. God is not a part of the order of natural substances, whose behavior reflects their essences in the ways described by laws of nature. Rather, he stands outside that order of natural substances as its cause, and thus stands outside the laws of nature that follow from the essences of those substances. And for the same reason, he is not part of the community of rational social animals, which is a part of that larger natural order and which is governed by natural law. Rather, he stands outside that community for the same reason that he stands outside the natural order as a whole, and thus stands outside the natural law for the same reason that he stands outside the laws of physics, chemistry, and the like.

Again, this by no means entails that God might arbitrarily make just any old thing morally obligatory, such as torturing babies for fun. God need not make beavers, trees, or

20 Ibid., pp. 130-34.

21 I thank an anoymous referee for pointing out the need for clarification here. 
any other physical substance at all. If he does not make them, then there will not be any laws of nature, because laws of nature presuppose the existence of physical substances whose natures the laws describe. Hence, since the very existence of laws of nature depends in this way on God, he can hardly be subject to them. All the same, if God does make such physical substances, then beavers will need trees and trees will need water, because that just follows from what it is to be a beaver or a tree. Similarly, God need not make human beings at all. And if he does not make them, then there will be no natural law, since the natural law presupposes the existence of rational social animals whose nature the natural law reflects. Hence, since the existence of the natural law in this way depends on God, he can hardly be subject to it. All the same, if God does make human beings, it will be bad for them to torture babies for fun, since that just follows from what it is to be a human being. To suppose (as Sterba appears to ${ }^{22}$ ) that God is either subject to natural law or liable to arbitrary commands and actions is, from the Thomistic point of view, to posit a false choice. And that there is intellect, will, supreme wisdom, and perfect goodness and justice in God by no means entails that every moral quality we attribute to human beings can intelligibly be attributed to him, or that he is subject to the Pauline Principle or other principles of natural law.

Sterba's arguments, like "god of the gaps" arguments, implicitly presuppose a conception of God as one part of the natural order alongside others, albeit an omnipotent, omniscient, and perfectly virtuous one-a "moral agent of the gaps," as it were. He compares God to a superhero who ought to be intervening to prevent evil the way that Spider-Man would. ${ }^{23}$ He also compares him to a just political state which has a duty to protect its citizens from criminals. ${ }^{24}$ In short, he operates with what I referred to earlier as a "theistic personalist" or "monopolytheist" conception of God. And since the world does not actually look the way we would expect it to if such a God-as-superhero or God-asjust-political-state existed, Sterba concludes that God does not exist. But for Thomists and classical theists more generally, the whole analysis is flatfooted, because that is simply not what God is in the first place. (As Aquinas says, "it would be absurd to praise God for His political virtues." ${ }^{25}$ )

Once again, the analogy of the author of a novel, though not exact, is useful. Sterba's argument is analogous to that of someone who conceives of a good author as a character in the novel who makes sure to prevent other characters from doing bad things-and then, when finding no such character upon reading the novel, concludes that the book has no author. Of course, that is not what an author, whether good or bad, really is. An author stands outside the novel altogether, and though for that reason he is not subject to the rules that govern characters within the novel, there are nevertheless distinctively authorial criteria by reference to which he can intelligibly be said to be a good author-such as skillful plotting, elegant prose, and the ability to construct a gripping story with a satisfying denouement. And an author who puts his characters through the wringer for a few chapters before reaching that denouement would be thought much better than one whose characters are boringly free of difficulty. God, for the Thomist, is analogous to such an author, having created a world whose order reflects his omnipotence and supreme wisdom, and which will culminate in the righteous living happily ever after and the wicked getting their just deserts.

\section{Further Problems}

So much for a general critique of Sterba's response to Davies. Let us now turn to addressing various specific points and criticisms raised by Sterba - which, as we will see, also tend either to misunderstand or beg the question against the Thomistic position. For example, Sterba's discussion of divine justice presupposes that God has obligations of

22 Ibid., p. 114f., where he raises the Euthyphro objection.

23 Ibid., p. 19.

24 Ibid., chapter 4.

25 Summa Theologiae I.21.1, quoted from (Fathers of the English Dominican Province 1948). 
justice to human beings in just the same sense in which we have such obligations to one another. ${ }^{26}$ But as we have seen, from the Thomistic point of view, the notion of commutative justice cannot apply to God at all, and the notion of distributive justice can apply to him only in a qualified sense.

When commenting on Davies' claim that God does not "intervene" in the natural order, Sterba appears to miss the point. ${ }^{27}$ In particular, he seems to think that Davies is not entirely consistent, insofar as Davies does not deny that God causes miracles. But what Davies means is that neither miracles nor anything else God does are "interventions" in the natural order in the sense in which a human being (who is one natural substance alongside others) might be said to "intervene" in events involving other natural substances, or in the sense in which a "god of the gaps" might "intervene" in the goings-on of a clockwork universe that otherwise operates independently of him. For, again, in the Thomistic view, God is not properly conceived of either on the model of one natural substance acting on others or as a "god of the gaps." But only if he were conceived of in either of those ways could it make sense to blame him for failing to "intervene" to prevent harm, in the way that a human being governed by natural law might be blamed for failing to intervene to prevent harm from befalling another human being.

Sterba says that if, as Davies allows, it would be contradictory for God to command us to do something that is contrary to our nature as rational agents, then it would also be contradictory for God not to follow the same moral laws to which we are subject, since he too is a rational agent. ${ }^{28}$ But this is doubly fallacious. First, the moral obligations we have under natural law follow from our nature as rational animals, specifically, not "rational agents" generically. Since God is not a rational animal, he would not be subject to the same laws we are even if he were subject to law in some other way (which he is not). Second, rationality is in any case to be predicated of God in an analogical sense, not in the same or univocal sense in which it is predicated of human beings. ${ }^{29}$

Sterba ignores the Thomistic account of goodness as actuality and of God's perfect goodness as a consequence of his pure actuality, even though these are among the considerations cited by Davies. ${ }^{30}$ Sterba does discuss another of Aquinas's arguments for God's goodness that is cited by Davies, but Sterba both misunderstands the argument and begs the question against it. ${ }^{31}$ Both Davies and Sterba formulate this argument as follows:

(1) All things seek their good (that which attracts).

(2) All things seeking their good are effects of God (things made to be by God).

(3) Effects are somehow like their causes.

(4) Therefore, the goodness which creatures are drawn to is like God, who can therefore be thought of as attractive (or good) like the goodness to which creatures are attracted.

Now, this would not be my own preferred way of reconstructing Aquinas's argument. I think his argument is much stronger than this formulation would indicate. But let that pass for present purposes, which are to show that Sterba's objections are not good ones. He says, first, that the argument presupposes "an Aristotelian worldview that is no longer credible today." ${ }^{\prime 2}$ But this begs the question against the Thomist, who argues that the relevant ideas from Aristotle are still defensible today. Indeed, recent years have seen a revival of mainstream interest in Aristotelian essentialism and teleology. ${ }^{33}$

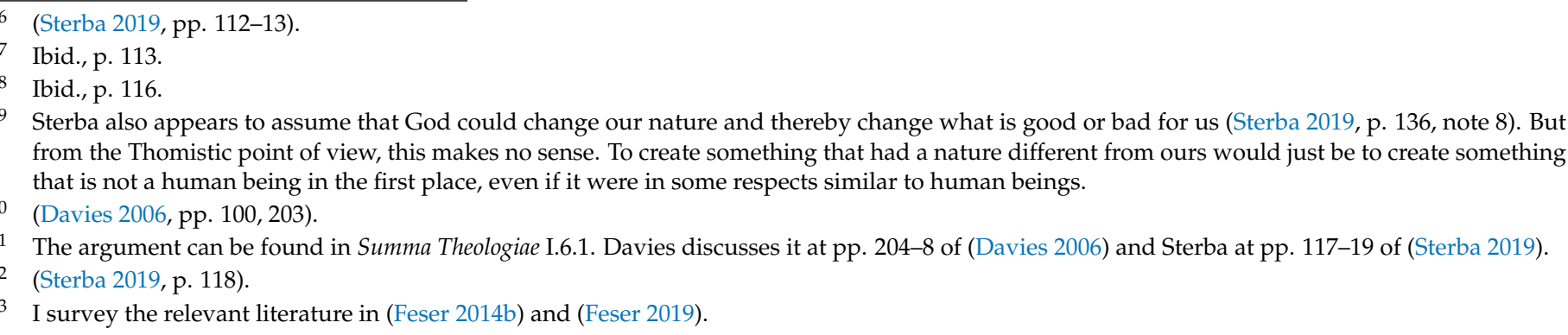


It does not help that Sterba seems to be operating with a superficial understanding of the key Aristotelian notions. For instance, though Davies devotes several pages to explaining exactly what Aquinas means by step (3), Sterba's objection does not engage with the thesis seriously. He cites what modern science says about the emergence of more complex forms from simpler ones as a counterexample, but as Thomists have pointed out, it is nothing of the kind. Later and more complex life forms do not arise from earlier and simpler forms alone, but from earlier and simpler forms together with genetic recombination and mutation and the environmental circumstances that determine the fitness of a trait. And the information content present in the effect does not outstrip that of the totality of these causal factors. Hence, the example does not conflict with Aquinas's premise (3), properly understood. ${ }^{34}$

Furthermore, to suggest, as Sterba does, that rocks do not aim at their own good and that this somehow refutes Aristotelian teleology is to attack a straw man. ${ }^{35}$ Properly understood, the teleology of any inorganic phenomenon has simply to do with its tendency to generate a certain characteristic effect or range of effects in a lawlike way, and this is as true of rocks as of anything else. ${ }^{36}$

Naturally, these metaphysical claims raise a number of questions and require further exposition and defense. The point, though, is that Sterba's criticisms of Thomistic theological claims are once again undermined by his failure to understand or seriously engage with the metaphysical underpinnings of those claims.

In explaining why God is not the cause of moral evil, Davies points out that in the Thomistic analysis, evil is a privation or the absence of a good that a thing ought to possess. God, the Thomist argues, causes what is good in a thing, but not the sorts of privations involved in moral evil, which are due to the sinner. In response, Sterba claims that if this would exonerate God from causing moral evil, it would exonerate the sinner as well. ${ }^{37}$ But this misses Davies' point. Davies is not saying that, because it is a privation, a moral evil does not in any sense have a cause (which would indeed entail that the sinner no more causes it than God does). He is merely saying that it is not the sort of privation of which God can be said to be a cause. But it still has a cause, namely the will of the sinner.

Related to this misunderstanding is Sterba's misunderstanding of Aquinas's view that God permits moral evil but does not will it even indirectly. Sterba says that if, as Davies says, God is the cause of the reality of things, then he must be causing moral evil and therefore willing it at least indirectly, not merely permitting it. ${ }^{38}$ But that does not follow, precisely because moral evil involves a privation or absence of reality, which absence God does not cause (though the sinner does), so God can intelligibly be said not to will it even indirectly but merely to permit it.

Finally, Sterba devotes a long discussion at the end of his chapter on Davies to trying to show that God cannot be exonerated for permitting the evil he does on the basis of appeal to any greater good he draws out of it. ${ }^{39}$ Various distinctions are made and thought experiments developed, but the whole treatment is vitiated by several fundamental begged questions and other mistakes. Some of these I have already mentioned. For one thing, the argumentation assumes that God is subject to the Pauline Principle-which, as I have argued, is not the case. For another, it fails to acknowledge, much less respond to, the Thomist position that the notion of commutative justice does not intelligibly apply to God and that distributive justice applies to him only in a qualified sense.

Another problem is that Sterba's discussion fixates on the loss of the worldly goods that those who suffer evil are deprived of, while ignoring the Thomist position that what ultimately matters are the goods of the next life-and, in particular, the supernatural end

For further discussion of this issue, see (Feser 2014b), pp. 154-59.

(Sterba 2019, p. 137, note 12).

For further discussion of this issue, see (Feser 2014b), pp. 88-105.

(Sterba 2019, p. 120).

Ibid., pp. 123-24.

Ibid., pp. 124-34. 
of the beatific vision, compared to which even the highest goods of this life are trivial. Furthermore, Sterba characterizes the harms of this life in terms of the frustration of the "preferences" of those who suffer such harms. But from the Thomistic point of view, what determines what is truly good for us are the ends toward which we are by nature and by grace directed, not the ends that we merely happen as a matter of contingent fact to want to pursue.

Hence, just as Sterba's attempt to revive the logical problem of evil presupposes too anthropomorphic a conception of God, so too does it presuppose too this-worldly a conception of human happiness. From a Thomistic point of view, he not only fails to hit the target, but has been aiming his fire in the opposite direction. ${ }^{40}$

Funding: This research received no external funding.

Conflicts of Interest: The author declares no conflict of interest.

\section{References}

Davies, Brian. 2006. The Reality of God and the Problem of Evil. London: Continuum.

Davies, Brian. 2021. An Introduction to the Philosophy of Religion, 4th ed. Oxford: Oxford University Press.

Fathers of the English Dominican Province, trans. 1948, Summa Theologica. New York: Benziger Bros, 5 vols.

Feser, Edward. 2009. Aquinas. Oxford: Oneworld Publications.

Feser, Edward. 2013. Kripke, Ross, and the Immaterial Aspects of Thought. American Catholic Philosophical Quarterly 87: 1-32. [CrossRef] Feser, Edward. 2014a. Being, the Good, and the Guise of the Good. In Neo-Aristotelian Perspectives in Metaphysics. Edited by Daniel D. Novotny and Lukas Novak. London: Routledge, pp. 84-103.

Feser, Edward. 2014b. Scholastic Metaphysics: A Contemporary Introduction. Heusenstamm: Editiones Scholasticae.

Feser, Edward. 2017. Five Proofs of the Existence of God. San Francisco: Ignatius Press.

Feser, Edward. 2018. Aquinas on the Human Soul. In The Blackwell Companion to Substance Dualism. Edited by Jonathan Loose, Angus Menuge and J. P. Moreland. Oxford: Wiley-Blackwell, pp. 88-101.

Feser, Edward. 2019. Natural Law Ethics and the Revival of Aristotelian Metaphysics. In The Cambridge Companion to Natural Law Ethics. Edited by Tom Angier. Cambridge: Cambridge University Press, pp. 276-96.

Hart, David Bentley. 2013. The Experience of God. New Haven: Yale University Press.

Mackie, J. L. 1955. Evil and Omnipotence. Mind 64: 200-12. [CrossRef]

Miller, Barry. 1996. A Most Unlikely God: A Philosophical Inquiry into the Nature of God. Notre Dame: University of Notre Dame Press. Plantinga, Alvin. 1977. God, Freedom, and Evil. Grand Rapids: Eerdmans.

Rowe, William L. 1979. The Problem of Evil and Some Varieties of Atheism. American Philosophical Quarterly 16: 335-41.

Shanley, Brian J. 2002. The Thomist Tradition. Dordrecht: Kluwer Academic Publishers.

Sterba, James P. 2019. Is a Good God Logically Possible? Cham: Palgrave Macmillan. 